\title{
Marketing Intangibles - The Legal Quest of Quantifying the Non-Measurable
}

\author{
Nitin S. Kondalwade Patil, Rupal Rautdesai
}

\begin{abstract}
A M P^{1}$ commonly referred as issue of marketing intangible in the Transfer Pricing ('TP') has been on the top list of revenue authorities for scrutiny not only in India but worldwide. In India, the issue has travelled through various Income tax ITATs to the various High courts. Still the same has not attained the required finality till date. The issue has been contested on various debates involving issue of consideration of incurrence of AMP expenditure as an international transaction, recovery of such expenses from associated enterprise (' $A E$ '), incurrence of AMP leading to brand promotion or brand building for Multinational Enterprises/groups ('MNE') etc.The problems develop directly out of the exact existence of a worldwide transaction to the computation of arm's duration cost ('ALP') of such global transaction. Much widely, the Tax Authorities ('TAs') are perceived as to be using the Bright Line Test ('BLT'), the place that the taxpayers AMP additionalityinvest vis-à-vis the competitors' equivalent is viewed according to the price of program for calculating the arm's measurements program earnings intended forthe advancement of thebrand name.As per the BLT application a mere quantified way might lead to illogical conclusions, and hence, this exercise intends to explore issues legally and with a legal perspective on the debatable questions related to marketing intangibles.
\end{abstract}

Keywords: -Arm's length Price, Associated Enterprises, Bright Line test, Courts, Direct taxes, ITATs, Intellectual Property, India, Marketing Intangibles, Multinational Enterprises, OECD and UN-TP, Tax authorities, Transfer pricing.

\section{INTRODUCTION}

TP is a legal scrutiny on alleged shifting of income from higher tax jurisdiction on the reduced tax jurisdiction or maybe tax paradise jurisdiction by the MNEs, in which, the tax regulations need the MNEs to exhibit theirtransactions performed in the arm's duration, i.e. rather than getting some effect of relatedshareholding over the mechanism of rates of transactions.

Many Multinational Groups ('MNC Groups') oppressively do worldwide strategic tax research, causing a few "abusive tax avoidance." A significant kind of abusive tax avoidance is transfer costs management, allowing MNC Groups to move earnings from maximized tax places to minimized tax places. By the associated party Transactions,the world industry is liberated as well as associated party transactions

Revised Manuscript Received on February 05, 2020.

* Correspondence Author

Nitin S. Kondalwade Patil*, Joint Commissioner of Income Tax, Mumbai, PhD Scholar at Symbiosis International (Deemed University), Pune, Maharashtra, India. (Email: patil.nitin.nadt@gmail.com)

Rupal Rautdesai, Symbiosis Law School, Pune, Symbiosis International (Deemed University), Pune, Maharashtra, India. (Email: rupal@symlaw.ac.in)

(C) The Authors. Published by Blue Eyes Intelligence Engineering and Sciences Publication (BEIESP). This is an open access article under the CC BY-NC-ND license (http://creativecommons.org/licenses/by-nc-nd/4.0/) under MNC Group universally comprise about partialto the entire industry done by the MNCs. Soit implies, financial ownership as well as transfer pricingperforms a tremendous aspectin world trade.

Of all the MNE Groups transactions of transfer pricing, intellectual property (IP) associated transfer prices would be the susceptible and important most to management. Seems an outcome of the value of IP that is mobility as well as considerable where also the intricacy of IP correlated problems. IP has worth that is huge since it usually creates or perhaps has got the possibility to create huge quantities of royalties. Provided that IP is an intangible papers advantage with no actual physical existence, it's effortlessly transferable from a single nation to yet another. IP-related monetary problems occur in business methods, valuation, and also accounting and in acknowledgement of earnings to tax resolutions. Given complex monetary problems are usually complicated along with in a flux state. So, tax circumvention via transfer pricinghandling of IP is a developing issue.

The concept of analysis of Functions implemented, Assets working and Risks supposed ('FAR analysis') is very important to determine the characterization of transacting entities inside the MNE Group, their relative involvement within the entire value chain and to identify the entrepreneurial entity, which is entitled to the residual profits within the value chain. Till recently, the world of TP was focusing upon the contractual relationship amongst the parties and the aspect of risk presumed a higher importance. This was more driven by the 'form' rather than 'substance', since the allocation of risks within the entities of the MNE Group was possible to be artificially manipulated. However, over a period of time, the Revenue authorities around the world realized that the key aspect for arm's length nature evaluation for the transfer prices within the MNE Group is the aspect of functions performed, since this reflected more of substance within the arrangement, rather than form. This leads to a distinction between legal owners of an intangible asset against the economic owner of the same.The Indian Transfer Pricing ('ITP') has developed over the decades. The originatedyears of transfer pricing scrutiny can see considerable litigation as well as focus associated with equivalent for deciding ALP. There continues to be a gradual change of emphasis of the tax authorities that is apparent with the strategy of theirs in the currently realized assessments.Among the stimulating aspects which happen to have emerged underneath the TP community may be the instances in which the Group businesses of an MNE invest considerable quantities on the AMP and the place that the manufacturer is run by an alternative entity in the Group.

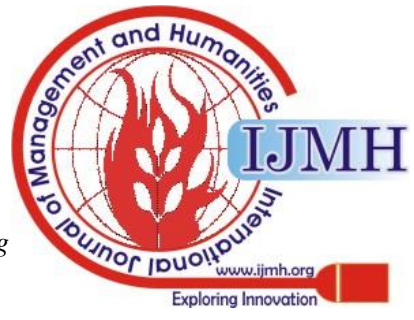


${ }^{1}$ Advertising, Marketing and Promotion expenditure.

The Tax Authorities ('TAs') have supposed that likewise Group businesses provide aconcealed / underlying transaction together by the entity having the emblem, in which, the surplus invest over AMP is for brand advancement,with no any/ sufficient remuneration to the Group entities investing the AMP. The TAs, after that, utilized the BLT, the place that the AMP invest of the taxpayer was in contrast to which of the excess as well as the opposition was labelled as the price towards the provision ofbrand promotion services and finally a TP adjustment was made by adding an arm's length mark-up to the cost of services, so identified.

There have been multiple decisions of Income Tax Appellate ITAT ('ITAT'), which have been adjudicated with contradictory decisions, since the entire focus of the TAs, taxpayers and the appellate authorities was either on the vociferous analysis of the financial data and BLT or on the legal aspects of the presence of transaction, etc., which are extreme ends of arguments. Any TP issue needs an understanding from an economic perspective, such as the arrangement between the parties, the cost-benefit analysis which a businessman would undertake, the medium-long term benefits which could be expected based on an additional marketing spend, nature of expenses, legal vs. economic ownership of the Intellectual Property ('IP'), the characterization of the respective entity and the benefits which could be expected by such entities, etc.

The issue of marketing intangibles had originated outside India. In India, the issue of marketing intangibles became the one of burning transfer pricing issues and involved a significant amount of transfer pricing adjustments. The issue has now reached at the Supreme Court level. Early this year, the Delhi High Court has pronounced a landmark ruling and laid down various principles to deal with this issue.

\section{MARKETING INTANGIBLE CONCEPT}

Before starting the discussion on intangibles of marketing, to understandIntangibles and marketing intangiblesmeaning is essential. Indian Transfer Pricing Regulations has not defined marketing intangibles. However, guidance can be taken from Organization of Economic Countries ('OECD') guidelines. These guidelines define intangible as -

“Intangibles ${ }^{2}$ include intellectual property ('IP') such as patents, copyrights, trademarks, service marks, trade names and trade secrets. IP normally indicates properties since the owner has the legal rights to exploiting them. However, in today's commercial world, intangibles could encompass business models, propriety procedures, processes, know-how, customer relationships, and supplier relationship management systems, marketing systems, information technology and many other categories of intangibles that bring value to the company."

The OECD has issued revised guidelines in 2017. The guidelines prescribed the definition of intangibles ${ }^{3}$ as follows:
“The word 'intangible' is intended to address something which is not a physical asset or a financial asset, which is capable of being owned or controlled for use in commercial activities, and whose use or transfer, would be compensated had it occurred in a transaction between independent parties in comparable circumstances.

Rather than focusing on accounting or legal definitions, the thrust of a transfer pricing analysis in a case involving intangibles should be the determination of the conditions that would be agreed upon between independent parties for a comparable transaction."

Marketing Intangibles_-"An intangible (within the meaning of paragraph 6.6) that relates to marketing activities aids in the commercial exploitation of a product or service and/or has an important promotional value for the product concerned. Depending on the context, marketing intangibles may include, for example, trademarks, trade names, customer lists, customer relationships, and proprietary market and customer data that is used or aids in marketing and selling goods or services to customers."

From the above, we can observe that OECD has broadened the scope of intangibles. OECD guidelines has more emphasised on value creation through intangibles rather than accounting treatment in financial statement.

One important TP issue which depends significantly upon the perception of economic possession is the issue of heavy Advertisement, Marketing and Promotion ('AMP') expendituressustained by a licensee entity within the Group, wherein, the allegation by the Revenue Authorities is that these expenses are incurred for the promotion of brand owned by the licensor entity within the Group, thereby, 'implying' a transaction of service by the licensee to the licensor, requiring remuneration. Whereas, the licensee tax payers have been claiming that they are the economic owners of the intangibles and hence the heavy AMP costs are incurred for their own benefit, which may accrue over a period of time. This issue is commonly referred to as the marketing intangible issue, since the $\mathrm{TP}$ aspects are dependent upon the marketing intangible of trade name/trademark/brand name and a possible intangible arising out of the heavy AMP expenses.

\section{ORIGIN OF DISPUTES}

To understand the issue better, it would be relevant to look at the genesis of the transfer pricing controversy around marketing intangibles. This issue first came up for consideration in the case of "DHL" before the US Tax Court. This was primarily on account of the 1968 US TP Regulations ('US TPR') which propounded an important theory relating to 'Developer-Assister rules ${ }^{6}$ '. This decision

\footnotetext{
${ }^{4}$ Glossary of OECD Guidelines, 2017

5 The legal framework for transfer pricing in the U.S. is contained in a number of sections of the internal revenue code, as well as in IRS regulations, mostly under Section 482. http://www.ustransferpricing.com/laws.html

${ }^{6}$ The decision in case of DHL for making adjustment on account of AMP expenses, applying Bright Line Test which was rendered in the context of a specific law viz. Developer-Assister Rule, in US TPR (US Reg. 482-4). https://www.law.cornell.edu/cfr/text/26/1.482-4

${ }^{2}$ Para 6.2 of OECD Guidelines, 2010

${ }^{3}$ Para 6.6 of OECD Guidelines, 2017 
was the pioneer of Transfer pricing decisions relating to 'marketing intangibles'.

DHL is an US incorporated company and in the year 1972 it formed a subsidiary called 'DHLI, Hong Kong' to handle all its international operations. DHL, USA owned the trademark and licensed it to DHLI, Hong Kong royalty-free, since DHLI registered the world-wide trademark and carried on other marketing activities. During the year under consideration, a Japanese company agreed to purchase the DHLI, Hong Kong stock for US\$ 450 million and DHL trademark at UNITED STATES \$20million in exchange for DHL receiving the right to use the trademark for 15 years' royalty-free and at a low royalty for ten years thereafter.

As per 'Developer - Assister' rule the developer being the person incurring the AMP spends (though not being the legal owner of the brand) was treated as an economic owner of the brand and the assister (being the legal owner of the brand), would not be required to be compensated for the use or exploitation of the brand by the developer. The rules lay down four factors to be considered:

a. The member'scapabilities to independently carry out the activity.

b. The grade of control derived by all entities.

c. The development activity location.

d. The relative risks and costs borne by all controlled entities.

The primary emphasis of the given rules seems to be equitable ownership primarily based on financial chance as well as expenditures. Authorized ownership isn't labeled as an element to be looked at in deciding what party is definitely the creator of the intangible home, though the exclusion of its isn't distinct. Nevertheless, the developer assister guideline had been amended in 1994, to incorporate, along with various other conditions, factor of' legal' ownership inside the gamut of its, for identifying the developer/owner of the intangible home, and also supply when the intangible home isn't legally shielded subsequently the creator of the intangible will likely be considered the proprietor.

Nevertheless, the US TPR understand that there's a difference between' routine' and' non-routine' spending as well as this particular distinction is crucial to analyse the controversy surrounding remuneration to be obtained by the household AE for advertising intangibles.

In the context of the above-mentionedrules, the Federal Tax Court in the case of DHL coined the idea of a' Bright Line Test' ('BLT') by differentiating the regular costs in addition to non-routine expenditures. In brief, it so long as for the dedication of the financial ownership of an intangible, there has to be a dedication of the non-routine (i.e. brand building) costs instead of the regular expenditures typically incurred by a distributor in advertising the product or service of its.

A crucial concept emanating out of the DHL ruling would be that the AMP spending must initially be analysed to see non-routine and routine spendingand accordingly, if at all, compensation may be sought possibly for the non-routine expenditure.
The AMP issue was, since then, picked up across the world and many authorities, including OECD and United Nations provided some guidance on this issue.

\section{GLOBAL PERPSECTIVE}

Following paragraphs provide a gist of guidance provided by various authorities -

\section{OECD Guidelines}

The OECD Guidelines in Chapter VI under paragraph 6.36 to 6.38 states the problems faced when tasks of marketing are performed by businesses not having trademarks or maybe industry labels that they're promoting, for example in case of distributor of goods.

The OECD Guidelines mention that such marketer who is undertaking marketing activities shall be remunerated whether as a provision provider or with a segment in supplementary return to marketing intangibles is attributable.

The Guidelines of OECD under paragraph 6.38 states the following associativewith intangibles of marketing attributable return-

"Distributor may bear extraordinary marketing expenditures beyond what an independent distributor in such a case might obtain an additional return from the owner of a trademark, perhaps through a decrease in the purchase price of the product or a reduction in royalty rate".

\section{United Nations Transfer Pricing Manual ('UN TP Manual')}

UN TP Manual allows for the provision of that price of market dispersion, advertising growth as well as industry upkeep techniques between an MNE and the subsidiaries of it underneath the TP Regulations.Para 5.3.2.5 of the TP hand allows for the price distributionof the techniques amidof the MNE as well as the subsidiaries of it is a crucial problem of $\mathrm{TP}$ and can rely on the logics as well as circumstances in every term.UN TP Manual in its Chapter 10, paragraph 10.4.8.12 to 18 has discussed the Indian position on intangibles.

The UN TP Manual in paragraph 10.4.8.15 has stated the steps in arm's length price determination in cases of intangibles ofmarketing. It has mentioned functional analysis, stages of development of marketing intangibles by Indian subsidiary, ascertaining who bears the cost of development and examination of remuneration model of Indian Subsidiary.

The UN TP Manual in paragraph 10.4.8.14 describes that includingintangibles of marketing in the terms ofIndian tax administration computes the ALP byresulting the perception of a "bright line" test but also faces lot of challenges and also provides for various contentions of the Taxpayers against the same.

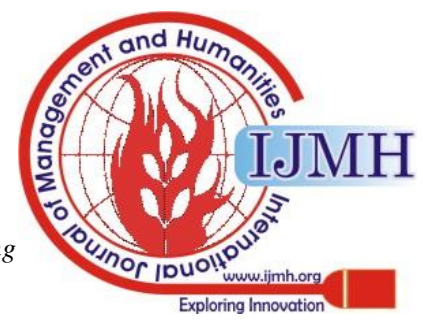




\section{Australian Tax Office (“ATO”) Guidelines}

The ATO has published a guide that illustrates the Tax Office perspective on the concepts for deciding a suitable incentive for advertising activities done through marketing intangible in association to an enterprise doesn't be particular.

The majorsubjects which figure out the technique for resolving this kind of circumstances are:

a. The contractual plans in amid of the industry tag proprietor \& internet marketer, particularly the period of the understanding, the dynamics of the rights received by the marketer in regard of the industry name, and that bears the expenses as well as risks associated withmarketing activities.

b. Whether the amount of advertising events done by the internet marketer surpasses which is done by equivalent impartial businesses.

c. The degreeover which activities of marketing will be predictable to advantage the name of the trade owner as well as/or the marketer, also

d. Whether adequately the marketer is remunerated for the activities of marketing of it through a typical reoccurrence on those pursuits or perhaps must there be a segment in an extra return on the industry name.

Accordingly, the ATO Guidelines concludes that in case enterprises not owning trademarks or trade names undertake marketing activities for its AE's benefits, then they should be compensated adequately.

\section{New Zealand TP Guidelines}

As per New Zealand's TP Guidelines, authorized ownership stays completely with the parent company, although the value of it is improved by itsmarketing activities inthe New Zealand subsidiary.

The marketing and advertising may be viewed as an assistance offered to the parent company, with reimbursement actually being furnished on a cost-plus origination.

\section{China TP Guidelines}

China is additionally growing its inspection range to incorporate community advertising intangibles, arguing that neighbourhoodmarketing activities produce extra revenue, that ought to be taxed in China.

The use of deemed transaction of AMP, when coupled with Circular 363, recommend a world where loss making entities will probably be inhibited destructively. Circular 363 probably says that particular, easy entities shouldn't incur losses under nearly every condition.

Thus, there exists enough international guidance on the TP aspects of AMP; however, there is no guidance as of the Indian Central Board of Direct Taxes $\left({ }^{\circ} \mathrm{CBDT}^{\prime}\right)^{7}$ on this

\footnotetext{
${ }^{7}$ The Central Board of Direct Taxes (CBDT) is a part of Department of Revenue in the Ministry of Finance. The CBDT provides inputs for policy and planning of direct taxes in India, and is also responsible for administration of direct tax laws through the IT Department. The CBDT is a statutory authority functioning under the Central Board of Revenue Act, 1963. The officials of the Board in their ex officio capacity also function as a division of the Ministry dealing with matters relating to levy and collection of direct taxes. The CBDT is headed by Chairman and also
}

issue. Moreover, the Indian tax law has its unique provisions, which also require clarifications on the corporate tax aspects of the issue of AMP.

\section{INDIAN PERSPECTIVE}

\section{Overview}

Transmit Pricing Litigation about Advertising marketing as well as revenue promo (AMP Expenses) along with the development of Intangibles of Marketing aimed at the global related business, has arrived at the front in the current decades. Over the lack of the law of statutory on the topic, the law created strictly through judicial pronouncements. In a regular model of MNC company, the Indian subsidiary experiences AMP costs to the marketing of its services or products. The Assessee has opposed the AMP cost is experienced always for the objective of marketing the services /products of it in the market of India or that they are the economic owners of the purported marketing intangibles, if any.

In previoustime, there are already Tax Department situations not permitting deduction of tax for this kind of costs on the foundation that the costs give the emblem of the worldwide related enterprise ('AE') in India also resultantly meanwhile the costs profit the global $\mathrm{AE}$ similar expenditures shouldn't be permitted as a tax inference in the dedication of taxable earnings of the Indian AE. Several judicial pronouncements have detained that the place that the spending was experienced for the reasons of small corporate of the Indian business, the transaction must be permitted as being aninference.

Appropriately, the problem (experiencing of AMP costs as well as development of the Intangibles of Marketing) has today joined the transfer pricing world of controversy. Tax Department contention is there because the Indian business incurs costs that profit the global AE, the Indian business must be repaid for this kind of expenditures.

In reality, the proposition continues to be that by marketing the emblem in India, the Indian subsidiary is giving a program on the global $\mathrm{AE}$, that it ought toget compensation (that may function as the recuperation of expenses incurred and a suitable mark up with \& previously likewise expenses). It's resisted by the Tax Department where such brand promotion and advertisement costs give rise to in development of marketing intangibles that should be to the $\mathrm{AE} \&$ ideal recompense for that brand promotion and advertisement costs was expected to be produced by the External AE.

Appropriately, In India the Transfer Pricing Officers ("TPOs"), implementing the' Bright Line Test' as placed down in the determination people Tax Court in DHL Inc.'s situation, have detained that the spending on ad as well as brand name promo costs that go over the typical of AMP costs incurred through the equivalent businesses in India, is

comprises six members, all of whom are ex officio Special Secretary to the Government of India.

Published By:

Blue Eyes Intelligence Engineering

\& Sciences Publication

(C) Copyriaht: All riahts reserved.

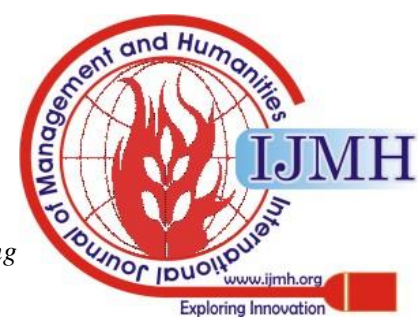


necessary to be compensated/reimbursed utilizing the international enterprise.

The fundamentalaccompanied by the Tax Department would be where the extra AMP investmentexperienced by the Indian AE suppliesin the direction of the growth as well as enhancement of the company belonging to the parent of multinational team (the global AE). This apparent enhancement in the valuation of the company is generally known by'marketing intangibles'.

Here's the deliberatedproblem that anywhere an Indian $\mathrm{AE}$ is interested to allocating recognized goods of its global $\mathrm{AE}$, along with the Indian AE incurs AMP spending for promoting the merchandise, whether in India as such costs are experienced for advertising of the item or even for creating the emblem of the global AE. The Tax Department must value the big alteration among merchandise promo as well as brand promotion. Product promo mainly focuses on a rise in the need for a specific product or service whereas Brand Promotion outcomes in development of Marketing Intangibles.

Where already numerous decisions choices (mainly ITAT Decisions) which happen to have mentioned the part of AMP spending that results to construction of the intangibles of marketing for the global AEs who've resulting advantages as well as TP changes in respect thereof. Nevertheless, the ITATs in the choices pronounced just before the retrospective amendments created through the Finance Act, 201219, in this respect, have detained that meanwhile the precise global transactions affecting to AMP bills haven't been described the TPO through the Assessing Officer ('AO') the presumption of the jurisdiction usageof the TPO in exercising the ALP of the AMP transaction isn't acceptable. Moreover, assessee, before the amendments created by the Act of Finance, 2012, have resisted that intangibles of the marketing per se weren't enclosed under the significance of the term "international transaction".

Nevertheless, the amendments carried by Finance Act, 2012 in the Indian Transfer Pricing Regulations empower the TPO to scrutinize some global transactions that the TPO believes healthy alsofurthermore, the meaning of the phrase global transaction have been broadened to deliver inside the ambit facility of its of solutions associated with the improvement of marketing intangibles.

\section{AMP: INDIAN JOURNEY}

\section{Maruti Suzuki (Delhi High Court) ${ }^{8}$}

While there have been numerous case laws on the issue of AMP by Indian Income Tax Appellate ITAT ('ITAT'), some of the decisions have been the milestones in the journey of TP litigation on AMP. The issue started with Maruti Suzuki's case at ITAT, which further travelled to High Court [Maruti Suzuki India Ltd vs. ACIT (2018) 191 TTJ 148 (Delhi)(Trib.)

In relationto the AMP appliesexperienced by Maruti Suzuki, the Delhi High Court laid down the givendirections a. If the AMP usually applies are at a range much like equivalent to the third-party makers, then the global entity wouldn't be asked to compensate the Indian entity.

b. If the AMP usually applies are substantially maximum compared to final party companies, the usage of foreign entity's logo is mandatory as well as the aidsresulting by the foreign entity are not accompanying, then the foreign entity would be mandatory to compensate the Indian entity.

Though, later, the Supreme Court remanded back the problem to the files of the Assessing Officer ('AO') toevaluate the issue in light of law, deprived of being biased with the of High Court decision.

\section{LG Electronics (Del. Trib.)}

Later, the special bench of ITAT adjudicated the issue by upholding that the AMP is an international transaction as well as BLT is an appropriate procedure to compute the Arm's Length Price ('ALP'), however, the special bench provided a partial relief to the Assessee by identifying the expenses, which need to be excluded from AMP, being in the nature of product promotion or pure advertisement for sales. The special bench opined that there nothing called 'economic ownership' within the provisions of the Indian Income Tax regime. The cases below are relied upon the decision of LG Electricals.

\begin{tabular}{|c|c|}
\hline Particulars & Citation \\
\hline $\begin{array}{l}\text { Whirlpool of India } \\
\operatorname{Ltd}^{9}\end{array}$ & $\begin{array}{l}\text { [2015] } 64 \text { taxmann.com } 324 \\
\text { (Delhi) }\end{array}$ \\
\hline $\begin{array}{lr}\text { Daikin } & \text { Air- } \\
\text { conditioning } & \text { India } \\
\text { (P.) Ltd. } & \\
\end{array}$ & $\begin{array}{l}\text { [2013] } 37 \text { taxmann.com } 14 \\
\text { (Delhi - Trib.) }\end{array}$ \\
\hline $\begin{array}{l}\text { Casio India Co. (P.) } \\
\text { Ltd. }^{11}\end{array}$ & $\begin{array}{l}\text { [2015] } 58 \text { taxmann.com } 375 \\
\text { (Delhi - Trib.) }\end{array}$ \\
\hline
\end{tabular}

\section{BMW India (Del. ITAT)}

In BMWcase of, the Delhi bench of ITAT notable the LG ruling and provided a relief to the assessee by adjudicating that no adjustment for AMP is required since the margins of the assessee are sufficiently higher than those of comparable. The main distinguishing point by the Delhi bench was that BMW was a distributor as against LG being a manufacturer.Following ITAT rulings followed the BMW rationale to provide relief to the taxpayers,
${ }^{9}[2015] 64$ taxmann.com 324 (Delhi)
${ }^{10}[2013] 37$ taxmann.com 14 (Delhi - Trib.)
${ }^{11}[2015] 58$ taxmann.com 375 (Delhi - Trib.) 


\begin{tabular}{|l|l|}
\hline \multicolumn{1}{|c|}{ Particulars } & \multicolumn{1}{|c|}{ Citation } \\
\hline $\begin{array}{l}\text { Casio India Co. (P.) } \\
\text { Ltd. }\end{array}$ & $\begin{array}{l}\text { [2015] 58 taxmann.com 375 } \\
\text { (Delhi - Trib.) }\end{array}$ \\
\hline $\begin{array}{l}\text { Bose Corporation } \\
\text { India (P.) Ltd. }{ }^{12}\end{array}$ & $\begin{array}{l}\text { [2014] 49 taxmann.com 24 } \\
\text { (Delhi - Trib.) }\end{array}$ \\
\hline $\begin{array}{l}\text { Motorola Solutions } \\
\text { India (P.) Ltd. }{ }^{13}\end{array}$ & $\begin{array}{l}\text { [2014] 48 taxmann.com 248 } \\
\text { (Delhi - Trib.) }\end{array}$ \\
\hline $\begin{array}{l}\text { Perfetti Van Melle } \\
\text { India (P.) Ltd. }{ }^{14}\end{array}$ & $\begin{array}{l}\text { [2015] 57 taxmann.com 390 } \\
\text { (Delhi - Trib.) }\end{array}$ \\
\hline $\begin{array}{l}\text { Ray Ban Sun Optics } \\
\text { India Ltd. }{ }^{15}\end{array}$ & $\begin{array}{l}\text { [2014] 45 taxmann.com 460 } \\
\text { (Delhi - Trib.) }\end{array}$ \\
\hline
\end{tabular}

Sony Ericsson (Delhi High Court)

Later, the Delhi High Court, in case of Sony, provided a substantial relief to the Indian distributors, wherein, the High Court upheld the presence of international transaction by way of heavy AMPs, rejected the application of BLT, since not prescribed within ITPR, adjudicated that the compensation for AMP can be direct or indirect, recognized the concept of economic ownership, accepting the benefit of AMP accruing to the assessee, based on a long term contract establishing economic ownership.Following ITAT rulings followed the Sony Ericsson rationale to provide relief to the taxpayers

\begin{tabular}{|l|l|}
\hline \multicolumn{1}{|c|}{ Particulars } & \multicolumn{1}{|c|}{ Citation } \\
\hline $\begin{array}{l}\text { Adobe Systems } \\
\text { Incorporated }\end{array}$ & $\begin{array}{l}\text { [2016] 69 taxmann.com } \\
228 \text { (Delhi) }\end{array}$ \\
\hline AT \& S India (P.) Ltd. ${ }^{17}$ & $\begin{array}{l}\text { [2016] 72 taxmann.com } \\
324 \text { (Kolkata - Trib.) }\end{array}$ \\
\hline Whirlpool of India Ltd ${ }^{18}$ & $\begin{array}{l}\text { [2015] 64 taxmann.com } \\
324 \text { (Delhi) }\end{array}$ \\
\hline $\begin{array}{l}\text { Mattel Toys (India) (P.) } \\
\text { Ltd }^{19}\end{array}$ & $\begin{array}{l}\text { [2016] 72 taxmann.com } \\
86 \text { (Mumbai - Trib.) }\end{array}$ \\
\hline $\begin{array}{l}\text { Discovery } \\
\text { Communications India }{ }^{20}\end{array}$ & $\begin{array}{l}\text { [2015] 64 taxmann.com } \\
120 \text { (Delhi - Trib.) }\end{array}$ \\
\hline Essilor India (P.) Ltd ${ }^{21 .}$ & $\begin{array}{l}\text { [2016] 68 taxmann.com } \\
311 \text { (Bangalore - Trib.) }\end{array}$ \\
\hline $\begin{array}{l}\text { GlaxoSmithKlineConsumer } \\
\text { Healthcare Ltd. }{ }^{22}\end{array}$ & $\begin{array}{l}\text { [2015] 64 taxmann.com } \\
84 \text { (Chandigarh - Trib.) }\end{array}$ \\
\hline Goodyear India Ltd. ${ }^{23}$ & $\begin{array}{l}\text { [2016] 70 taxmann.com } \\
67 \text { (Delhi - Trib.) }\end{array}$ \\
\hline $\begin{array}{l}\text { Honda Siel Power Products } \\
\text { Ltd }^{24} \text { [2015] 64 taxmann.com }\end{array}$ \\
\hline
\end{tabular}

\footnotetext{
12 [2014] 49 taxmann.com 24 (Delhi - Trib.)

13 [2014] 48 taxmann.com 248 (Delhi - Trib.)

14 [2015] 57 taxmann.com 390 (Delhi - Trib.)

15 [2014] 45 taxmann.com 460 (Delhi - Trib.)

${ }^{16}$ [2016] 69 taxmann.com 228 (Delhi)

${ }^{17}$ [2016] 72 taxmann.com 324 (Kolkata - Trib.)

${ }^{18}$ [2015] 64 taxmann.com 324 (Delhi)

19 [2016] 72 taxmann.com 86 (Mumbai - Trib.)

20 [2015] 64 taxmann.com 120 (Delhi - Trib.)

21 [2016] 68 taxmann.com 311 (Bangalore - Trib.)

22 [2015] 64 taxmann.com 84 (Chandigarh - Trib.)

23 [2016] 70 taxmann.com 67 (Delhi - Trib.)
}

\begin{tabular}{|c|c|}
\hline Particulars & Citation \\
\hline India Medtronic (P.) Ltd. ${ }^{25}$ & $\begin{array}{l}\text { [2016] } 66 \text { taxmann.com } \\
218 \text { (Mumbai- Trib.) }\end{array}$ \\
\hline $\begin{array}{l}\text { Bausch \& Lomb India (P.) } \\
\text { Ltd. }^{26}\end{array}$ & $\begin{array}{l}\text { [2015] } 59 \text { taxmann.com } \\
448 \text { (Delhi - Trib.) }\end{array}$ \\
\hline
\end{tabular}

The Delhi HC ruling has cleared various ambiguities of the whole issue by providing detailed guidance on the transfer pricing treatment of the non-routine AMP expenses.However, there are still few open questions on which further debate is possible, e.g. a) Whether AMP expenses can be considered as international transaction in every scenario in which licensor and licensee operate b) whether the guidance or ratio of the $\mathrm{HC}$ ruling is equally applicable in case of licensed manufactures.

In subsequent paragraphs, the author has evaluated open points pertaining to marketing intangibles.

\section{Whether incurring of AMP is an international transaction?}

While Section 92B(1) defines the term international transactions and includes the 'marketing intangibles' in the same, the moot point is whether the issue of AMP expenses incurred by Indian entity falls within the purview of marketing intangibles when such intangibles are legally owned by the global foreign entity; Also, in what situation can the Indian taxpayer be said to be contributing towards development or enhancement of marketing intangibles legally owned by an global Group entity?

The allegation by the Indian Revenue Authorities ('IRA') is that the Indian taxpayers have incurred excess AMP, thereby, providing brand development/brand promotion services to the global Associated Enterprise ('AE'). In such a situation, the issue is not about marketing intangibles, but an 'implied'/ 'embedded' service transaction, which is undertaken without receipt of a service fee. Moreover, a plain vanilla comparison of AMP costs with the comparable will not provide a conclusive proof that the expenses are incurred towards promotion of a brand on account of following reasons:

01. The taxpayer may be a late entrant in the market and may need to incur heavy AMP costs to create market awareness for the 'branded products' to facilitate sales, as opposed to 'promotion of a brand',

02. The nature of expenses need to be considered as to whether the expenses are towards 'promotion of branded products for higher sales' or for 'promotion of brand' itself,

03. The choice of mode of advertisement/promotion also is important, e.g., if an entity chooses to have a mass television advertisement, then its costs will certainly be higher than those of an entity choosing the print media as the mode of advertisement.

\footnotetext{
24 [[2015] 64 taxmann.com 328 (Del)

25 [2016] 66 taxmann.com 218 (Mumbai- Trib.)

${ }^{26}$ [2015] 59 taxmann.com 448 (Delhi - Trib.)
}

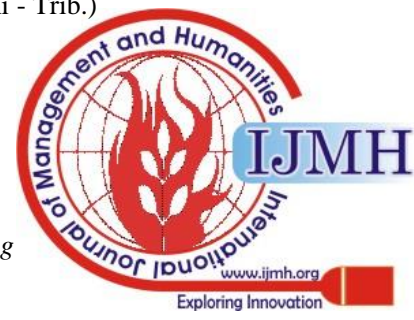


Considering the above, it is important to be very clear as to whether:

04. The taxpayer has incurred an expense for its own business and on its own account and whether the benefits of such an expenditure will accrue to the taxpayer itself for a foreseeable future, i.e. whether the taxpayer is an 'economic owner' of the intangibles/benefits accruing out of the heavy AMP costs even though it is not the legal owner of the brand? Or

05. The taxpayer is a simplicity service provider, having no recourse to the future economic benefits and hence a service provider to the brand owner on account of heavy AMP costs?

Thus, the situation (I) may lead the issue of heavy AMP to development of 'marketing intangible' on own account, whereas, the situation (II) will lead to an issue of 'implied'/ 'embedded' transaction of service provision without a remuneration. Thus, only under circumstances similar to a situation (II), the AMP costs can be considered as an international transaction.

a) Once the existence of international transaction is determined, whether there needs to be a separate compensation for such international transaction or such compensation can be in an indirect form, such as by way of reduction in the price of products imported by the Indian entity from the global AE?

It would be important to clarify the circumstances where the margins earned by the Indian taxpayer shall be considered to be adequate and no separate compensation is insisted upon for the excessive AMP expenses incurred by the Indian entity, forexample: - where the intercompany contract and pricing provides for an indirect compensation to the Indian entity such as by way of reduction in the price of products imported by the Indian entity from the global AE. Moreover, it would also be important to provide guidance on the identification of comparable in such cases, since, identification of comparable with lower AMP spends/absence of AMP function may not provide an appropriate basis for evaluating the adequacy of margins earned by the taxpayer.

Further, the CBDT should also identify parameters for categorizing the benefits of AMP spend of an Indian taxpayer as 'incidental benefit' to the global legal owner of the brand, which is not an intra-group service, as per the OECD guidelines.

\section{ECONOMIC OWNERSHIP}

While the Special bench of ITAT in case of LG clearly disregarded existence of any 'economic ownership, the Delhi High Court in case of Sony has recognized the concept of 'economic ownership'. The High Court dealt with this issue by stating that the onus to demonstrate economic ownership is on the taxpayer; however, there is no guidance in terms of objective parameters as to what constitutes an economic ownership.

A mere existence of a long term contract may not constitute an economic ownership, unless such a contract is entered into based on arm's length circumstances and terms and conditions. Such terms should clearly bring out that the licensee is an economic owner of the intangibles and any enhancement thereto. Such a contract may need a clear clause on the pre-mature termination of such a long term contract and specify the manner of computation of 'exit charge', if any.

If a contract doesn't comply with the test of 'arm's length behaviour' and does not address some of the points mentioned above, it may be difficult for a taxpayer to demonstrate the economic ownership and in such a case, the taxpayer may get categorized as a service provider to the owner of brand, requiring a remuneration.

Following references to other guidance may help the CBDT for this purpose:

A. It is interesting to note that the Organization for Economic Cooperation and Development ('OECD') also has recognized the concept of economic ownership, by bringing out the key functions in relation to the intangibles, based on Development, Enhancement, Maintenance, Protection and Exploitation ('DEMPE').

B. The Japanese administrative guidelines (Para 2.12) also specify that for a licensing transaction for an intangible property, not only the legal ownership, but also the contribution of respective entities in the formation, maintenance and development of it also need to be considered.

C. A guidance can also be drawn from the Circular 6 of 2015 by the CBDT, where, for the applicability of TNMM, the CBDT refers to important parameters, such as actual supervision and control as well as the ability to do so, the strategic functions, such as conceptualization, etc.,

D. The United Nations ('UN') Transfer Pricing Manual ('TPM') discusses the concept of economic ownership in Chapter 5, wherein it states that the economic ownership of a trademark/trade name can be created based on such entity's contribution in the strategy of enhancing the market share.

\section{TAX ON ECONOMIC OWNERSHIP}

If the economic ownership is established, it is clear that the heavy AMP may not be an international transaction. However, assuming that the economic ownership is established, it is important for the CBDT to come up with guidance on the following aspects:

\section{Under what circumstances should the economic ownership need remuneration?}

While the economic owner is expected to reap the benefits of the asset for itself, it would be important to specify whether a pre-mature termination of a long term contract would need a remuneration for the 'economic ownership', calling it as 'relinquishment'/'extinguishment' of contractual rights under the scope of Section 2 (27) of the Act or whether the remuneration is required by way of an 'exit charge'.

\section{Chargeable head of taxation}

It would be important to identify whether the remuneration against economic ownership is taxable

i. Under the head Profits and Gains of Business and Profession ('PGBP') in terms of Section 28 (iv), i.e. any value of any benefit arising from business or Section 28 (va), i.e. for non-compete reasons, or

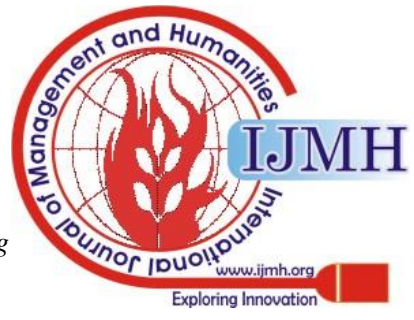


ii. Under the head capital gains, treating the premature termination/non-renewal of a long term contract as 'relinquishment'/'extinguishment' of a capital asset under Section 2 (27) or a transfer of contractual rights as referred to in Section 32 of the Act.

\section{Clarifications required if the remuneration is taxable} under the head capital gains.

If the remuneration against the economically owned intangible is considered to be taxable as capital gains, it would be important to get guidance on following important aspects:

i. Cost of acquisition of asset: Whether the same should be considered as NIL as per the provisions of Section 55 of the Act, treating the asset as 'self-generated' asset, or considering the costs incurred and royalties paid on development of assets as the cost of acquisition.

ii. Availability of indexation: It would also be important to get clarity on the availability of indexation for the economically owned intangible and the parameters for determining the period of holding for such an asset.

iii. In case the cost of acquisition/indexation doesn't get any clarity, the machinery of taxation of capital gains itself would fail, thereby making the remuneration as nontaxable, as per the verdict of the Supreme Court in case of B. C. Srinivas Shetty.

\section{Clarifications required if the remuneration is taxable as PGBP}

OECD provides a guidance that mere transfer of functions/risks would not require any compensation by way of exit charge, unless, such a transfer is coupled with the transfer of assets. Assuming that the situation is a bundled situation of transfer of functions and assets (extinguishment $=$ transfer), and further assuming that the exit charge is required and is taxable as PGBP, a guidance is further required on the manner of computation of the exit charge.

\section{Non applicability of TP provisions}

If a conclusion is drawn that the exit charge/remuneration is neither taxable as PGBP nor as Capital Gains, then the provisions of Chapter $\mathrm{X}$ of the Act itself (i.e. the entire TP provisions) will not apply since the machinery Section 92 refers to computation of 'income' having regard to the arm's length price, implying thereby, that the precondition for TP is 'taxable income'.

Whether the pre-mature cancellation / non-renewal of a long term contract is an international transaction of 'business restructuring' or a transaction of transfer of 'marketing intangibles.

This would be important since there could be an ambiguity in interpreting the above situation as 'transfer' of the marketing intangibles. Moreover, a business restructuring is an international transaction, irrespective of the fact whether it has any impact on the profits/income/assets, etc.

\section{Reporting requirements and documentation}

The CBDT should also come up with a guidance on the manner of reporting the TP aspects of the AMP costs in the Accountant's Report (in prescribed Form 3CEB), since the taxpayer may take a position that there exists an economic ownership, thereby, negating any existence of an international transaction. Moreover, the CBDT should also provide guidance on the documentation to be maintained to demonstrate the appropriateness of the AMP costs, the existence of the economic ownership, etc.

\section{Constituents of routine and non-routine AMP costs.}

While the special bench of ITAT has provided guidance on the routine AMP costs, i.e. costs for promotion of products, it would be important for CBDT to come up with guidance on this aspect. It may be possible to clarify that only non-routine AMP costs may need evaluation around the economic ownership/'underlying' or 'implied' or 'embedded' service transaction.

\section{Method for computation of ALP for the AMP service}

From the above discussion, one of the outcome is that one can completely disregards the issue of marketing intangibles. However, the burden is on the tax payer to prove that it has incurred routine AMP expenditure. This whole exercise is very much factual and quantification of benefits is not very straightforward.

Before the ruling of Sony Ericsson by Hon'ble Delhi High Court, the tax authorities had considered bright line test as a tool for benchmarking AMP expenses. Hon'ble High Court has rejected method of computation of ALP using BLT for non-routine AMP expenses. Further Delhi HC has established a principle by stating that ALP shall be computed as per method prescribed under Indian Transfer Pricing Guidelines.

Payment made towards AMP expenses is a third party transaction and it is not in nature of related party transaction. The benchmarking of AMP expenses may pose challenges to taxpayers since business of comparable and tax payer could be different in terms of market, target audience, strategies. However, no guidance is available on this aspect in order to perform comparability adjustment.

In case of Sony Ericsson, Hon'ble Delhi High court has provided guidance on benchmarking of AMP expenses. The same are as follows:

\section{Aggregation of transaction and application of TNM Method}

The High Court held that distribution and marketing are intertwined and may be examined as bundled transaction. Clubbing of closely linked transaction is permissible under law. However closely link is a precondition for aggregation. For example,transaction for import of raw material for manufacturing may not be aggregated with distribution activity due to absence of close linkage. High Court held that it would be inappropriate to proceed with ALP determination with a pre-conceived supposition that each transaction must be analyse separately. The High Court also observed that in case the tested party is engaged in single line of business, there is no prohibition in applying Transactional Net Margin Method on entity wide basis.

Published By:

Blue Eyes Intelligence Engineering \& Sciences Publication

(C) Copyriaht: All riahts reserved.

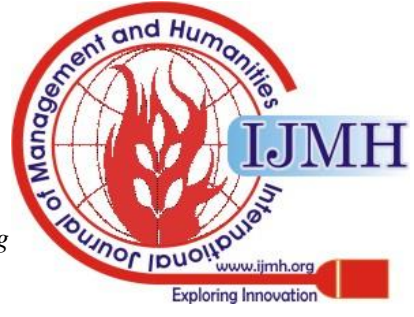


Further the High Court objected the manner of application of TNMM by the TPO and held that AMP expense cannot be segregated and benchmarked separately. The first step would be to undertake functional analysis and finalise comparable for application of TNMM after which, once net margins are compared, AMP expenses is already factored is in the analysis. Separately benchmarking AMP expenses under such case would lead to incongruous results.

The High Court also noted that when suitable comparableis not available and it is not possible to make suitable adjustment, it would be advisable to adopt and apply other method.

\section{Segregation of non-routine AMP expenses using BLT approach lacks acceptability}

The High Court ruled that while applying the BLT, the Tax Authorities have measured all the tax payers by similar yardsticks without focusing on the facts of the case. The High Court rejected the contention of tax department to bifurcate AMP expenses into routine and non-routine for the purpose of application of BLT.

The High Court ruled that value of brand depends upon the nature and quality of products and services sold or dealt with. Treating brand building as equivalent to AMP expenses would be largely incorrect. Taxpayers do not undertake advertisement with the purpose to increase the value of brand but to increase sales and thereby earn higher profits.

Focusing more on the importance of functional profile and characterisation of entities, The High Court discussed that in case of normal distributor, undertaking marketing and distribution function, it should be examined whether distributor is adequately remunerated by of lower purchase price, reduced payment of royalty or payment in any other form. The observation of Delhi High Court is in line with the findings of Delhi ITAT in BMW ruling, where it was held that in case a distributor has been provided additional gross margin by way of reduced purchase price, there is no need to make separate payment for AMP. The high court also observed that low risk distributor, undertaking minimal marketing and distribution function, would be entitled to lower but fixed profits and issue of AMP expenses would not be relevant for such a distributor.

\section{CONCLUSION AND WAY FORWARD}

The Issue of marketing intangibles has evolved in past few years. The High Court ruling was landmark ruling which sets essential principles to law to be applied while dealing with this issue. The HC ruling brought in the fundamentals of transfer pricing while determining the ALP of AMP expenses. These fundamentals should be relied upon by the taxpayer while analysing the arm's length treatment of AMP expenses.

While application of BLT is rejected by the Delhi HC, the HC granted relief by holding that if bundled transactions are concluded to be at arm' s length by applying the TNMM or $\mathrm{RPM}$, then there is no need to bifurcate and treat AMP activities as a separate transaction. This is a great relief for the taxpayers those who have earned a good amount of margins and still faced significant transfer pricing adjustments on account of AMP expenses.

Issue of marketing intangible requires an in-depth factual analysis, depending upon the functions, assets and risk profile of each taxpayer and its AE. This analysis should support characterisation of an entity.

As a way forward, it would be important for taxpayer to ensure that appropriate functional and economic analysis is captured in TP documentation itself and TP documentation should provide appropriate TP policies for its related party transaction.

\section{REFERENCES}

1. 1968 US TP Regulations ('USTPR')

2. Circular 6 of 2015 by theCBDT

3. Japanese administrative guidelines (Para2.12)

4. OECD Guidelines in Chapter VI under paragraph 6.36 to6.38

5. Para 5.3.2.5 of the TPmanual

6. SupremeCourtincaseofB.C.SrinivasShetty.(128 ITR294SC)

7. The world's 200 largest MNE Groups represent over one-fourth of the world's GDP. See Sarah Anderson \& John Cavanagh, Corporate Empires, MULTINAT'L MONITOR, Dec. 1996, available athttp://multinationalmonitor.org/hyper/mm1296.08.html

8. UN Manual in its Chapter 10, paragraph 10.4.8.12 to18

\section{References of Caselaws}

9. $\quad$ AT \& S India (P.) Ltd. [2016] 72 taxmann.com 324 (Kolkata - Trib.)

10. Adobe Systems Incorporated [2016] 69 taxmann.com 228 (Delhi)

11. Bausch \& Lomb India (P.) Ltd. [2015] 59 taxmann.com 448 (Delhi Trib.)

12. Bose Corporation India (P.) Ltd. [2014] 49 taxmann.com 24 (Delhi Trib.)

13. Casio India Co. (P.) Ltd. [2015] 58 taxmann.com 375 (Delhi - Trib.)

14. Daikin Air-conditioning India (P.) Ltd. [2013] 37taxmann.com 14 (Delhi -Trib.)

15. Discovery Communications India [2015] 64 taxmann.com 120 (Delhi -Trib.)

16. Essilor India (P.) Ltd. [2016] 68 taxmann.com 311 (Bangalore - Trib.)

17. GlaxoSmithKline Consumer Healthcare Ltd. [2015] 64 taxmann.com 84 (Chandigarh-Trib.)

18. Goodyear India Ltd. [2016] 70 taxmann.com 67 (Delhi -Trib.)

19. Honda Siel Power Products Ltd. [2015] 64 taxmann.com 328 (Delhi)

20. India Medtronic (P.) Ltd. [2016] 66 taxmann.com 218(Mumbai-Trib.)

21. L'Oreal India (P.) Ltd. [2016] 69 taxmann.com 419 (Mumbai - Trib.)

22. Mattel Toys (India) (P.) Ltd. [2016] 72 taxmann.com 86 (Mumbai Trib.)]

23. Mondelez India Foods (P.) Ltd. [2016] 70 taxmann.com 112 (Mumbai -Trib.)

24. Motorola Solutions India (P.) Ltd. [2014] 48 taxmann.com 248 (Delhi -Trib.)

25. Perfetti Van Melle India (P.) Ltd. [2015] 57 taxmann.com 390 (Delhi -Trib.)

26. Ray Ban Sun Optics India Ltd. [2014] 45 taxmann.com 460 (Delhi Trib.)

27. Thomas Cook (India) Ltd. [2016] 70 taxmann.com 322 (Mumbai Trib.)

28. TVS Motor Company Ltd.2017] 77 taxmann.com 105(Chennai-Trib.)

29. Whirlpool of India Ltd [2015] 64 taxmann.com 324(Delhi)

\section{AUTHORS PROFILE}

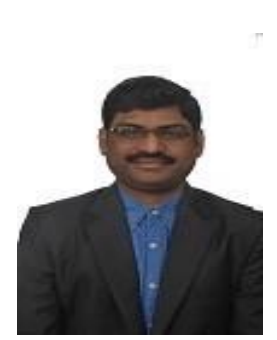

Nitin S. Kondalwade Patil, Masters in computer science, Ll.B, LL.M. (INTERNATIONAL LAW), MASTERS in Business Law, PhD (Law scholar).

Nitin S. Kondalwade Patil is an IRS (Indian Revenue Service) officer in the Income Tax Department presently posted in Mumbai. He hasdoneMasters in computer science. from SRTM University, LLB from SavitribaiPhule Pune university Pune and LL.M.in International law and contemporary (Law)fromNew Law College, Bharti deemed university, Pune., Masters in Business Lawfrom the NALSAR, Hyderabad. Diploma in management from IIM, Lucknow.

Published By:

Blue Eyes Intelligence Engineering \& Sciences Publication

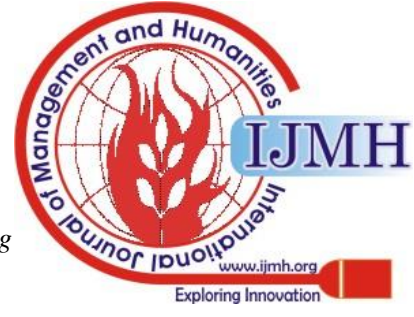


Currently, he is pursuing Ph.D. in intangibles (transfer pricinginternational taxation) from Faculty of Law, Symbiosis International Deemed University. He was the research analyst at the CMC India Ltd. He is the guest faculty for various carrier competition academies. He has represented India and participated in OECD module held at Ankara, Turkey.

His research interest includes International Taxation, Transfer pricing, Income Tax, Intellectual Property Laws, political science, computer science and public administration. He has published journal articles, research papers in SCOPUS indexed journals.

He has presented papers in various national and international conferences/ seminars with focus on transfer pricing.

\section{Publications:}

I. Nitin Kondalwade Patil, Dr. Rupal Rautdesai, Dr. Shashikala Gurpur (06/2018) Paper On Law Reforms InThe Income Tax Act 1961 In Relation To Marketing Intangibles (Advertisement, Marketing And Sales Promotion) IJER - Volume 9 Issue 3 ISSN:2229-6158.(National)

II. Nitin Kondalwade Patil, Dr. Rupal Rautdesai, Dr. Shashikala Gurpur (06/2018) Advertisement, Marketing and Promotion Expenses Amp' Brief Study Of Cost-Benefit Relations Pertaining To Amp Expenses In Indian Markets Vis-À-Vis Emerging Trends, IJER - Volume 9 Issue 3 ISSN: 2229-6158. (National)

III. Nitin KondalwadePatil, Dr. RupalRautdesai, (01/2020) Paper On "'Intellectual Property Rights and Multi National Enterprises- A perspective on taxation of Advertisement, Marketing and Promotion expenses of IPR in Indian context"' International Journal of Scientific \& Technology Research (IJSTR) Volume 9 - Issue 1, January 2020 Edition.(International SCOPUS)

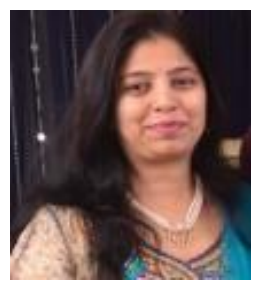

Dr. Rupal Rautdesai, B.Sc. LL.B. LL.M. PhD. NE Dr. Rupal Rautdesai graduated in Science after which she found her passion in Law. This led her to get a Bachelor and subsequently a Masters in Law from V.M. Salgaocar College of Law, Miramar, Goa. She has completed her doctorate in Law from Veer Narmad South Gujarat University, Surat and her research wason "Subject Matter of Patent: A comparative study with reference to India, United States and United Kingdom". Her area of specialization is Intellectual Property Rights. She is registered as a Patent Agent with the Indian Patent Office.

After obtaining her degree in Law, she practiced as an Advocate for two years and then joined into fulltime teaching since 2005. She has more than 13 years of experience in teaching. She has guided several LL.M. students in the last 10 years. She is also a recognised $\mathrm{PhD}$ supervisor (Guide) and has 6 students pursuing $\mathrm{PhD}$ under her guidance. Further she provides consultations in the field of Intellectual Property to researchers, students and faculty members across seven faculty/Departments in Symbiosis International University for last 5 years. She has published several research papers on contemporary topics of Intellectual Property Rights and International Taxation. She has conducted invited sessions and symposiums during her visit to Leibniz University at Hannover, Germany in 2011 and Chuo University at Tokyo Japan in 2015 respectively. Further she has conducted workshops in the field of Intellectual Property Rights and has keen interest in research and community outreach programmes.

\section{Publications:}

1. Gurpur Shashikala, Rautdesai Rupal (11/2014) Revisiting Legal Education for Human Development: Best Practices in South Asia. Procedia - Social and Behavioral Sciences, 157: 254-265 (Science Direct; ISSN: 1877-0428).(National)

2. Rautdesai Rupal (12/2014) Patents and Patentability Strategy in India: An Alert for Inventors. Symbiosis Contemporary Law Journal, 2(1): 97-115 (ISSN: 978-93-5143-018-6).(National)

3. Rautdesai Rupal, Ahmed Munnazzar (06/2014) Sustainable Development via Green Technology: A Patent Perspective. Online International Interdisciplinary Research Journal, 4: 233- 241 (DOAJ; ISSN: 2249-9598).(National)

4. Rautdesai Rupal, Nandekar Ujwal (03/2017) Online Photographs in News: Copyright Perspective. Media Watch, 8(1): 133-140 (Scopus; ISSN: 2249-8818). InternationalScopus

5. Nitin Kondalwade Patil, Dr. Rupal Rautdesai, Dr. Shashikala Gurpur (06/2018) Paper On Law Reforms inThe Income Tax Act 1961 In Relation to Marketing Intangibles (Advertisement, Marketing and Sales Promotion) IJER - Volume 9 Issue 3
ISSN:2229-6158.(National)

6. Nitin Kondalwade Patil, Dr. Rupal Rautdesai, Dr. Shashikala Gurpur (06/2018) Advertisement, Marketing and Promotion Expenses Amp' Brief Study of Cost-Benefit Relations Pertaining to Amp Expenses InIndian Markets Vis-À-Vis Emerging Trends, IJER - Volume 9 Issue 3 ISSN: 2229-6158. (National)

7. Rupal Rautdesai, Ujwal Nandekar, Aditya Kedari, Yogesh Patil, (05/2019) "Big data and privacy - A legal perspective and comparative study of United States and India" International Journal of Process Management and Benchmarking, ISSN online: 1741816X ISSN print: 1460-6739 International Journal ScopusIndexed

8. Nitin Kondalwade Patil, Dr. Rupal Rautdesai, (01/2020) Paper On "'Intellectual Property Rights and Multi National Enterprises- A perspective on taxation of Advertisement, Marketing and Promotion expenses of IPR in Indian context"'" International Journal of Scientific \& Technology Research (IJSTR) Volume 9 - Issue 1, January 2020 Edition.(International SCOPUS).

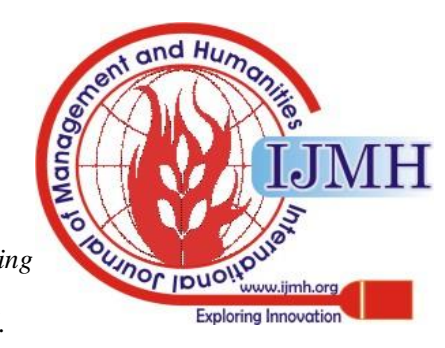

